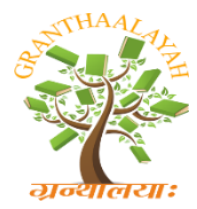

Social

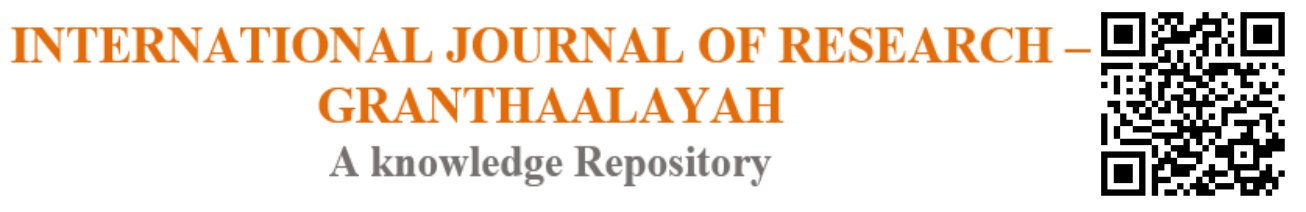

\title{
OBTAINING HALAL CERTIFICATE FOR PROCESSED ANIMAL FOOD IN GARUT REGENCY IS CONNECTED WITH THE REQUIREMENTS OF HALAL ABATTOIR ACCORDING TO THE REGULATION OF THE MINISTER OF AGRICULTURE OF THE REPUBLIC OF INDONESIA
}

\author{
Yeti Sumiati " ${ }^{\text {1, }}$ Tatty A. Ramli ${ }^{1}$, Faiz Mufidi ${ }^{1}$, Jejen Hendar ${ }^{1}$, Hilmi Ayu ${ }^{1}$, M. Dwivo \\ Rahayu ${ }^{1}$, Rais M. Shidiq ${ }^{1}$ \\ ${ }^{1}$ Faculty of Law, Universitas Islam Bandung, Indonesia
}

\begin{abstract}
Skin crackers are foods whose raw materials come from animals. As one of the leading culinary products in Garut Regency, the production of Sukaregang skin crackers is the result of people's economic activities that contribute to improving economic prosperity. Law No. 33 of 2014 concerning Halal Product Guarantee will be effective in 2019, where halal products are required to have a halal certificate, before including the halal label on the packaging. The purpose of this article is to analyze the acquisition of processed animal skin certificates in Garut Regency from the perspective of the Minister of Agriculture's regulation. The conclusion of this article is that Halal products must meet the halal and thayyib requirements. Products whose raw materials come from processed animals must come from Halal Certified Abattoirs, raw materials for Sukaregang skin crackers originating from leather supplied from Abattoirs that have no evidence that these raw materials are sourced from halal certified abattoirs, so 2019 targets are difficult to meet and will affect the people's economy. In Indonesia, there are still few Slaughterhouses that have been halal certified, as well as in Garut Regency there are no Halal Slaughterhouses that are certified.
\end{abstract}

Keywords: Skin Crackers; Halal Certificate; Slaughterhouses.

Cite This Article: Yeti Sumiati, Tatty A. Ramli, Faiz Mufidi, Jejen Hendar, Hilmi Ayu, M. Dwivo Rahayu, and Rais M. Shidiq. (2019). "OBTAINING HALAL CERTIFICATE FOR PROCESSED ANIMAL FOOD IN GARUT REGENCY IS CONNECTED WITH THE REQUIREMENTS OF HALAL ABATTOIR ACCORDING TO THE REGULATION OF THE MINISTER OF AGRICULTURE OF THE REPUBLIC OF INDONESIA.” International Journal of Research - Granthaalayah, 7(9), 342-350. https://doi.org/10.29121/granthaalayah.v7.i9.2019.617.

\section{Introduction}

Free trade and the Asian Economic Community (AEC) today have an increasing impact on the circulation of food and beverage products both locally and imported in the community. A Muslim is encouraged to obtain halal food, medicine and cosmetics with high quality standards. For a Muslim, it is his duty to consume any halal product [1]. Food and beverage products circulating in 
the community may not necessarily give a sense of security, comfort, security and are suitable for consumption by Muslim consumers, because Islamic law requires Muslims to consume halal food and drinks according to Islamic law.

Halal products are now a consumption trend throughout the world, both in Muslim and nonMuslim countries. No less than USD 650 million of halal product transactions occur every year. In Indonesia the majority of consumers are Muslim consumers for whom the need for food and drink is not just a trend or lifestyle, but more than that, is part of the manifestation of worship to Allah SWT [2].

For the safety of Muslim consumers, businesses must provide true and complete information. How not, safe and secure for Muslim consumers is not only measured from the perspective of health science and standards determined by law alone, but moreover it must be in accordance with Islamic legal guidance, namely Halalan Thoyyiban. Not only halal delicious but true in the process. Halal food and thayibb must pay attention to several things including (1) halal substance, (2) halal how to get it, (3) halal how to process it, (4) halal in its storage and (5) halal in its presentation [3].

The 1945 Constitution of the Republic of Indonesia Article 29 paragraph (2) mandates the State to guarantee the independence of each resident to embrace their respective religions and to worship according to their religion and belief. To guarantee every religious adherent and carry out his religious teachings, the State is obliged to provide protection and guarantee regarding the halal of products consumed and used by Muslim consumers, namely by establishing a Halal Product Guarantee regulation, which is contained in Law No. 33 of 2014 concerning Product Guarantees Halal.

The Halal Product Guarantee Act will come into force in 2019, this country's policy was conveyed in the National Coordination Meeting by the Director of the LPPOM MUI (Indonesian Institute of Food, Drugs and Cosmetics Study). There is a change in nature in halal certification from volunteer to mandating [4]. With the provision becoming an obligation for business actors to obtain the halal certificate, then this becomes a transition for business actors to change the acquisition of halal certificates which were originally only voluntary, turned into an obligation.

The requirement to put halal labels on product packaging must be supported by the ownership of the Halal Certificate. Through halal certificates there will be legal certainty for consumers over the sense of security that the product complies with Islamic law. Obedient Muslims certainly take great care of the halal products they consume. This indicates his adherence to the teachings of religion that have set it clearly. Therefore, it is important for Muslims to guarantee the halal status of the products they consume. Currently there are many products in circulation, but not all of these products are halal for consumption. This could be due to the process or material to make it composed of various elements which are forbidden.

Guaranteed implementation of Halal Products certainly provides comfort, security, safety, and certainty of the availability of Halal Products for the public in consuming and using Products, as well as increasing added value for Business Actors to produce and sell Halal Products, besides this Halal Product Guarantee becomes an opportunity to expanding market reach, business actors are 
certain to be able to produce sustainably and have an impact on economic prosperity for business actors.

For the people in Garut regency, the business activity of processing leather becomes one of the special foods in Garut regency, which is the food of skin crackers which are found in the Sukaregang Garut Skin Crackers Center. And this activity is made as a main activity carried out by the surrounding community. So that this activity becomes an economic activity for the surrounding community. As well as being the main income for the surrounding community and is a community economic activity and contributes in building the people's economy. Besides seeing the market trends, which are dominated by Muslim consumers, of course they ask for Halal products. So that the 2019 halal products including skin crackers, given the trend towards the direction of Muslim consumer interest where Muslim consumers will buy products that are guaranteed halalism and threaten the economy of the people who do not have halal certificates.

In addition, products whose raw materials come from processed animals must come from Halal Certified Abattoirs, raw materials for Sukaregang skin crackers originating from buffalo skin supplied from outside Garut Regency, which do not have evidence of these raw materials sourced from Abattoirs, whereas in Garut Regency itself does not yet have Halal certified slaughterhouses, this makes an obstacle faced by Sukaregang Leather cracker business actors in obtaining halal certificates, so what are the conditions that must be fulfilled in the Slaughterhouse in Garut district? And who are those who play a role in realizing Halal Slaughterhouse in Garut Regency?

\section{Results and Discussions}

In preparing for 2019, the year of the effective implementation of the Halal Product Guarantee Act (UUJPH). For products whose raw materials come from animals, of course, is closely related to the Abattoir. Animal Slaughterhouse is a building or complex of buildings with certain designs and conditions that are used as slaughterhouses for general public consumption which aim to carry out: a) Slaughtering animals properly, (in accordance with veterinary public health requirements, animal welfare and religious sharia) ; b) Animal health examination before slaughter (ante-mortem inspection) and carcass and postal inspection (post-mortem inspection) to prevent transmission of zoonotic diseases to humans; c) Monitoring and surveillance of animal diseases and zoonoses found in ante-mortem examinations and post-mortem examinations for the prevention, control, and eradication of infectious animal diseases and zoonoses in the area of origin of animals.

This is due to see the origin of the raw materials used as the main ingredients of skin crackers. As well as to avoid slaughtering halal failures, this is another obstacle for business actors because the difficulty of monitoring the use of raw materials in slaughtering requires a special expertise in identifying meat from animals whose slaughter is not in accordance with Islamic law or the term halal failure [5]. Skin derived from halal animals can become halal if slaughtered without following Islamic Sharia rules. The things that become critical points of the slaughtering process are as follows: a) Slaughterer (must be a Muslim who is obedient and carries out Islamic Sharia daily); b) Stunned (does not cause the animal to die before being slaughtered); c) Tools or knives (must be sharp); d) Post-slaughter process (animals must really die before the next process and blood must come out completely) [6]. 
The raw material for meat used must be obtained from a halal-certified shop or abattoir as described in the guidelines for meeting the criteria for a halal guarantee system in abattoirs [5]. When the abattoir does not yet have a predetermined standard, even does not yet have a Halal Certificate, it will have an impact on business actors who take and depend on the abattoir. One of them is inhibiting the obtaining of halal certificates on skin cracker products. For Muslim consumers, halal certificates have several functions, namely protecting Muslim consumers from non-halal food. Consumers are psychologically calm, besides maintaining their body and soul from deterioration due to illicit products, and will provide legal certainty and protection [7].

\subsection{Provisions for Fulfillment of Halal Certified Slaughterhouses}

Fulfillment of slaughterhouses that are halal certified must meet the Halal Assurance System (SJH) provisions issued by the Indonesian Ulema Council (MUI) and the requirements for the establishment of slaughterhouses issued by the Ministry of Agriculture. Halal guarantee system is a framework that is monitored continuously and reviewed periodically to provide effective direction for the implementation of halal production process activities [8]. In fulfilling the SJH issued by the MUI, it must at least meet the following requirements: a) Halal Policy, Top Management must establish a Halal Policy and disseminate halal policy to all company stakeholders; b) Halal Management Team, Top Management must establish a Halal Management Team that includes all sections involved in critical activities and have clear duties, responsibilities and authority; c) Training and Education, Companies must have written procedures for conducting training; d) Materials, Materials used in the manufacture of certified products may not come from unclean or unclean materials; e) Products, sensory characteristics of products must not have a tendency to smell or taste that leads to illicit products or that have been declared haram based on MUI fatwa. Product brands registered for certification may not use names that refer to something that is forbidden. Retail food products (retail) with the same brand circulating in Indonesia must be registered entirely for certification, not allowed if only partially registered; f) Slaughterhouse Production Facilities, including: 1) Slaughterhouses facilities are only devoted to the production of halal animal meat; 2) Slaughterhouses locations must be significantly separated from Slaughterhouses or pig farms; 3) If the deboning process is carried out outside of the Slaughterhouses, it must be ensured that the carcass is only from halal Slaughterhouses; 4) Slaughter equipment must meet the requirements; g) Written Procedures Critical Activities must be owned by the company, namely activities in the production chain that can affect the halal status of the product; h) Traceability, the Company must have written procedures to guarantee the traceability of certified products derived from materials that meet the criteria (approved by LPPOM MUI) and produced in production facilities that meet the criteria (free of pig material or derivatives); i) Handling Products that Do not Meet the Criteria, the Company must have a written procedure for handling products that do not meet the criteria, that is not being sold to consumers who require halal products and if they are already sold, they must be withdrawn; j) Internal Audit, the Company must have written internal audit procedures for implementing the $\mathrm{SJH}$; $\mathrm{k}$ ) Management Review, Top Management or its representatives must conduct a management review at least once a year, with the aim of assessing the effectiveness of the application of SJH and formulating continuous improvement [9].

In addition, the government in this case provides regulations related to the standardization of Slaughterhouses namely in the Regulation of the Minister of Agriculture of the Republic of 
Indonesia Number 13/Regulation of the Minister of Agriculture/OT.140/1/2010 concerning Requirements for Ruminant Animal Slaughterhouses and Meat Cutting Plant, requires three that is, Slaughterhouse Requirements, Meat Handling Unit Requirements and Hygiene and Sanitation Requirements.

\subsubsection{Slaughterhouses Requirements}

In this Slaughterhouses requirements include several requirements, to support the activities of the Slaughterhouses, including:

1) Technical Requirements of Slaughterhouses. In this requirement Slaughterhouses must be able to provide safe, healthy, whole and Halal meat, this activity must guarantee that slaughter and slaughtering of these animals must be in accordance with religious law. This is stipulated in article 17 paragraph (3) which reads Material derived from animals as referred to in paragraph (2) letter a is basically halal, except forbidden according to Sharia. Sharia provisions regarding animals that are forbidden are in accordance with the word of Allah SWT in QS. An Nahl verse 115 and Al-Baqarah verse 175. From these two verses Allah SWT clearly explains animals that should not be eaten are carcasses, blood, pork, and animals that (when slaughtered) are called (names) besides Allah. This stipulation was later adopted in Article 18 UUJPH (Halal Product Guarantee Act). Then UUJPH explains in article 19 which reads: (1) Animals used as material Products must be slaughtered in accordance with the Shari'a and meet the rules of animal welfare and veterinary public health; (2) The slaughterhouse as referred to in paragraph (1) is carried out in accordance with the provisions of the legislation. The provisions of article 19 are provisions regarding the procedure for slaughter, which must be in accordance with Islamic law, in this case based on the explanation of article 8 of the UUJPH that BPJPH (Halal Product Guarantee Agency) cooperates with the government in agriculture;

2) Location Requirements. In meeting the Slaughterhouses location requirements, at least meet a number of things including; the location of the Slaughterhouses is not located in a disaster-prone area, the area of pollution and is located far from community settlements and has sufficient access to clean water. In addition it is located separately between Slaughterhouses and Slaughterhouses of Pigs which is limited by a wall fence with a minimum height of 3 (three) meters to prevent traffic of people, equipment and products between slaughterhouses. With this location requirement it is expected to be able to guarantee the hygiene and purpose of Slaughterhouses namely Safe, Healthy, Whole and Halal can be realized;

3) Supporting Facilities Requirements. In fulfilling the minimum supporting prerequisites, it must include several aspects including good road access, water sources that meet clean and sufficient water quality standards, and adequate and continuously available sources of electrical energy, as well as handling liquid and solid waste. So that with a good and proper road access it is expected to facilitate the distribution and transportation process that is not obstructed, besides that it must also fulfill adequate and clean water sources. In addition, the minimum source of electric power is sufficient for all activities in the Slaughterhouses and is available continuously and is equipped with facilities to secure liquid and solid waste;

4) Layout, Design and Construction Requirements. In this requirement the most and must be fulfilled, related to the layout of Slaughterhouses include several buildings, namely the 
main building, animal settlement area, special shelter for productive female ruminant livestock, isolation cage, refrigerated withering room, loading area of carcass or meat, office Veterinary administration and offices, canteens and prayer rooms, employee break rooms, bathrooms and toilets, carcass destruction facilities, waste handling facilities and guard houses. As for the Slaughterhouses layout, the minimum includes: a) the deboning room and the cutting room; b) meat packing room (wrapping and packing); c) chiller facilities; d) freezer and blast freezer facilities; e) cold storage. As for the basic design and construction requirements, all buildings and equipment of Slaughterhouses must be able to facilitate the application of good production methods and prevent contamination. Also in the requirements to get a Veterinary Control Number (NKV) must meet these requirements. So this will be a matter relating to the fulfillment of two conditions, namely the Slaughterhouses and NKV conditions.

5) Equipment Requirements. In the equipment requirements, at least Slaughterhouses fulfills several things, namely: a) All supporting and supporting equipment in Slaughterhouses must be made of materials that are not easily corrosive, easily cleaned and disinfected and easy to maintain; b) All equipment and surfaces that come in contact with meat and edible offal must not be made of wood or toxic materials; c) All metal equipment that is in contact with meat and edible offal must be made of non-corrosive or corrosive, strong, unpainted, easily cleaned and easily disinfected and easy to care; d) Lubricants for equipment in contact with meat and offal must be food grade (safe for food); e) Hand washing facilities must be designed in such a way that they do not come in contact with the palm of the hand, equipped with facilities such as liquid soap and dryers, and when using tissue must be provided with a trash bin. This is intended so that hygiene will be guaranteed and maintained. As well as providing a legal certainty for the community and other business actors, even the most important is for Muslim consumers.

6) Meat Handling Unit Requirements (UPD). In meeting the requirements of this meat handling unit, several other supporting requirements are required, which include: a) Slaughterhouses Technical Requirements; b) Location Requirements; c) Supporting Facilities Requirements; d) Layout, Design and Construction Requirements.

7) Hygiene and Sanitation Requirements. The fulfillment of hygiene and sanitation requirements requires there to be other supporters, which include the following requirements: 1) Slaughterhouses and UPD must be equipped with hygiene-sanitation facilities that can ensure that the means of producing carcasses, meats, and innards can be applied properly and consistently. This is intended to guarantee the hygiene of the manner and process of activities carried out at Slaughterhouses and UPD; 2) That in order to guarantee safe, healthy, whole and halal animal origin food and in order to realize the health and peace of mind of the people, hygiene and sanitation is very important to ensure cleanliness and of course halal. Some studies report that contamination can also occur if the equipment used in cutting and transportation is unhygienic; 3) At each entrance of the main building, must have facilities for washing boots equipped with shoe brushes, and facilities for disinfecting boots equipped with disinfectants (foot dipping); 4) Slaughterhouses and UPD must have hand washing facilities that are equipped with warm water, soap and disinfectants and are designed not to be operated by hand or are not in direct contact with the palm of the hand; 5) Hand washing facilities must be equipped with hand dryer facilities, if using tissue paper, a trash can with a lid and not operated by hand must be provided; 6) To disinfect the knives and equipment used, must have a temperature 
of not less than $820 \mathrm{C}$ that meets the requirements for clean water quality standards, or other effective sterilization methods; 7) Do not use hazardous chemicals that are not allowed to be used for food; 8) After each process of cutting and producing carcasses, meats, and innards, a thorough cleaning and disinfection process must be carried out; 9) Environmental cleanliness around the main buildings in the Slaughterhouses and UPD complex areas must be maintained periodically, by keeping the environment clean, maintaining grass and trees and providing temporary waste disposal facilities.

\subsection{Parties Who Play a Role in Addressing Halal Certified Slaughterhouses in Garut Regency}

Not only do Slaughterhouses have slaughterers who have been certified, but Slaughterhouses themselves must have halal certificates as stated in the previous discussion. In realizing Slaughterhouses that have Halal characteristics, it takes the role of various parties, not only the livestock service, but other parties also play a role, including:

1) Department of Industry and Commerce. The role in supporting the creation of halalcertified Slaughterhouses is not enough from one agency or government agency, but it needs synergy between related agencies in implementing and encouraging the creation of halal Slaughterhouses. In this case the role of the industry and trade service are: 1) Encouraging the Livestock Service in creating halal certified Slaughterhouses, by showing the number of Home and SME industries that depend on Slaughterhouses in creating competitiveness with products outside the region and even abroad; 2) Establish cooperation with the trade and industry services and livestock services from outside the area that supply leather raw materials; 3) Synergize and capture business actors who take raw materials from abroad or import raw materials must use applicable standards and procedures, not through middlemen.

2) Department of Cooperatives and SMEs. The Department of Cooperatives and SMEs in supporting the creation of halal Slaughterhouses that is synergizing with other agencies in creating Halal Slaughterhouses, besides that the Office of Cooperatives and SMEs must be able to provide an understanding of SMEs and cooperatives in taking raw materials must be in accordance with predetermined procedures, in order guarantee the comfort and safety of consumers.

3) Animal Husbandry Service. Animal Husbandry Department is the most vital service and has a lot of roles in the implementation of halal certified Slaughterhouses. In terms of realizing Slaughterhouses which is halal certified, the Animal Husbandry Department is expected to be able to: 1) Provide support in terms of funding to complete and perfect the facilities needed at Slaughterhouses to support the creation of Halal certified Slaughterhouses; 2) The animal husbandry office encourages the regional government to allocate a budget related to the employment of all facilities needed in creating halal certified Slaughterhouses; 3) Animal husbandry service through Slaughterhouses must be able to carry out: a) Slaughtering animals properly, (in accordance with veterinary public health requirements, animal welfare and religious sharia); b) Animal health examination before slaughter (ante-mortem inspection) and carcass and postal inspection (post-mortem inspection) to prevent transmission of zoonotic diseases to humans; c) Monitoring and surveillance of animal diseases and zoonoses found in ante-mortem and post-mortem examinations for the prevention, control and eradication of infectious and zoonotic animal 
diseases in the area of origin of animals; d) Meet the requirements of the NKV certificate; 4) Animal husbandry service must be able to provide human resources as referred to in article 41 and article 42 of the Ministry of Agriculture Slaughterhouses.

4) Garut Regency Indonesian Ulema Council. MUI in the process of creating halal Slaughterhouses plays a very important role besides the livestock service, which is as follows: 1) Supporting and synergizing with the livestock service in providing directives related to facilities that must comply with religious law; 2) Supporting and synergizing in allocating funds for the procurement of supporting facilities for Slaughterhouses that are certified as halal, this is seen from the high response of the public and business actors to halal products; 3) Petrified and smoothed in realizing halal Slaughterhouses in providing direction, advice and input in accordance with religious law in terms of human resources in this case slaughterers and veterinarians and other technical requirements.

\section{Conclusion}

After discussion, the minimum requirements that must be fulfilled by Slaughterhouses are at least meet the Slaughterhouses Technical Requirements, Location Requirements, Supporting Facilities Requirements, Layout, Design and Construction Requirements and Equipment Requirements, as well as the requirements of the MUI which include: halal policy, halal management training team and education, materials, products, slaughterhouse production facilities, written procedures, critical activities, traceability, handling of products that do not meet criteria, internal audits and management reviews. While those supporting the roots of the creation of Halal Certified Slaughterhouses include the Cooperative and SMEs Service, the Health Service, the Industry and Trade Service, the Agriculture and Animal Husbandry Office and the Indonesian Ulema Council both in support of the provision of funds for the provision of facilities and the direction of human resources based on religious law.

\section{References}

[1] Sayekti, Nidya Waras, (2014). Jaminan Produk Halal Dalam Perspektif Kelembagaan. Jurnal Ekonomi \& Kebijakan Publik, Vol. 5 No. 2.

[2] Aryani, Tatty, Andai Konsumen Muslim Adalah Raja, diakses dari https://hukum.unisba.ac.id/andai-konsumen-muslim-adalah-raja-hj-tatty-aryani-ramli-s-h-m-h/

[3] Murjani, "Sistem Jaminan Produk Halal Dan Thayib Di Indonesia: Tinjauan Yuridis Dan Politis", Jurnal Fenomena, Volume 7, No 2, 2015.

[4] Safira, Maya, "Tahun 2019 produk tanpa sertifikat halal dilarang beredar di Indonesia", diakses dari https://food.detik.com/read/2017/04/05/210130/3466268/294/tahun-2019- produk-tanpasertifikat- halal-dilarang- beredar-di- Indonesia.

[5] Maryati, T. dkk, (2013) Analisis Faktor Kendala dalam Pengajuan Sertifikat Halal. (Studi Kasus: Pelaku Usaha Mikro, Kecil dan Menengah Makanan Beku di Jabodetabek). Jurnal Ilmu Produksi dan Teknologi Hasil Peternakan.

[6] Lembaga Pengkajian Pangan Obat-Obatan Dan Kosmetika Majelis Ulama Indonesia. (2008). Panduan Umum Sistem Jaminan Halal LPPOM - MUI. Jakarta: LPPOM-MUI.

[7] Hasan, KN. Sofyan. (2014). Kepastian Hukum Sertifikasi dan Labelisasi Halal Produk Pangan. Jurnal Dinamika Hukum, Vol. 14 No. 2.

[8] Mardesci, Hermiza. (2013) Pangan Halal Dan Cara Memilih Produk Kemasan Yang Aman Dan Halal. Jurnal Teknologi Pertanian, Vol. 2, No. 2. 
[9] Lembaga Pengkajian Pangan Obat-Obatan Dan Kosmetika Majelis Ulama Indonesia. (2012). Persyaratan Sertifikasi Halal, HAS 23000, Persyaratan Sertifikasi Halal: Kriteria Sistim Jaminan Halal, HAS 23000: 1. Jakarta: LPPOM MUI.

*Corresponding author.

E-mail address: unisba.yeti@gmail.com 